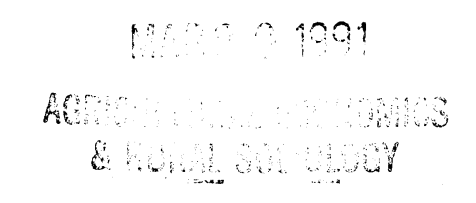

Economics and Sociology

Occasional Paper No. 1775

\title{
INFORMAL FINANCE THROUGH LAND PAWNING CONTRACTS: EVIDENCE FROM THE PHILIPPINES
}

\author{
by \\ Geetha Nagarajan \\ Cristina C. David \\ and \\ Richard L. Meyer \\ March, 1991

\begin{abstract}
Paper presented at the XXI International Conference of Agricultural Economists

Tokyo, Japan, August 22-29, 1991
\end{abstract} \\ Agricultural Finance Program \\ Department of Agricultural Economics \\ and \\ Rural Sociology \\ The Ohio State University \\ 2120 Fyffe Road \\ Columbus, Ohio 43210-1099
}




\begin{abstract}
Land pawning contracts in which the pawner temporarily transfers his land cultivation rights to the pawnee in return for a loan with an agreement to redeem it on loan repayment have increased in importance in Philippine rice growing villages. This paper uses cross sectional data from farm households in five heterogenous production environments to analyze the determinants of the choice of pawning contracts. The analysis shows that land pawning is an informal credit instrument used by small farmers to obtain large loans to finance productive investments, such as non-farm employment, where the returns to investment are high. An econometric model was developed to examine the factors affecting the choice of pawning contracts and the observed loan size. The results suggest that farm households with poorer quality land, smaller farm sizes and lower physical and human assets pawn out land, while wealthier farm households with larger farm sizes and greater physical and human assets pawn in. The observed loan size is explained by reputation of pawners and rice cropping intensity in the region.
\end{abstract}

\title{
Acknowledgements
}

We acknowledge with appreciation the valuable suggestions provided by Keijiro Otsuka and Ma. Agnes R. Quisumbing of the International Rice Research Institute in developing the research problem, and to Dale W Adams of the Ohio State University for insightful discussions. We also acknowledge AID/Washington and the USAID mission in Manila for financial support provided to OSU for research on the financial sector in the Philippines. The usual disclaimers apply. 


\title{
INFORMAL FINANCE THROUGH LAND PAWNING CONTRACTS: EVIDENCE FROM THE PHILIPPINES
}

\author{
by
}

\author{
Geetha Nagarajan, Cristina C. David, and Richard L. Meyer ${ }^{1}$
}

Informal finance has become the main source of rural credit in the last two decades in the Philippines (Adams and Sandoval; Bautista and Magno). High risk and lending transaction costs, and the lack of collateral of small farmers, coupled with regulated interest rates, led to credit rationing by formal financial institutions. A number of mechanisms involving collateral substitutes have been developed in the informal financial markets mainly through the interlinkage of credit with labor, land, and product markets to lower transaction costs and risks. The nature of the mechanisms that emerge depends primarily on the technological and institutional features of the rural sector (Binswanger and Rosenzweig).

Land pawning contracts represent one type of collateral substitute used in informal markets to obtain large loans for purposes and for borrowers for which formal loans are difficult or impossible to obtain. Although pawning contracts are widely used in Asia, the pawning of land cultivation rights is a recent phenomena in the Philippines (Adams and Sandoval; Esguerra and Meyer; Onchon; Wijaya and Sturgess). The recent pawning contracts are a modification of sangland bili contracts under the pacto de retroventa (sale

1 Geetha Nagarajan is a Graduate Research Associate, Department of Agricultural Economics and Rural Sociology, The Ohio State University, USA. Cristina C. David is an Economist, International Rice Research Institute, Philippines; Richard L. Meyer is a Professor, Department of Agricultural Economics and Rural Sociology, The Ohio State University, USA. 
with an option to repurchase) arrangement used by the Chinese settlers in the early eighteenth century to acquire 'fee tail' land (land transferable to only legitimate heirs) through money lending ${ }^{1}$. Nagarajan, Quisumbing and Otsuka argued that land pawning contracts recently emerged because of increased credit demand in rice growing areas where land reform restricted land transfers, where technological innovations in rice farming conferred a transaction value to cultivation rights, and where credit markets were not well developed ${ }^{2}$.

In a pawning transaction, the pawner temporarily transfers his cultivation rights to the pawnee in return for a loan, and can redeem these rights upon loan repayment. During the contract period, the returns from the land accruing to the pawnee, who assumes all operating expenses including any land rental payment, represent implicit interest earned (paid) by the pawnee (pawner). A permanent transfer of cultivation rights may occur if a large loan is not repaid after a long period of time.

This paper examines the determinants of choice of pawning contract by farmers in rice growing areas. The study is based on a cross-section analysis of farm households in five villages representing a heterogenous production environment for growing rice. The next section describes the study villages and characteristics of pawning contracts. After discussing the conceptual model in the third section, section IV presents the results of the econometric model used to explain the determinants of pawning contracts. The final section discusses policy implications. 


\section{Description of the Study Villages and Pawning Contracts}

The data used in this study were obtained from a survey conducted by the International Rice Research Institute for its study of the "Differential Impact of Modern Rice Technology Across Production Environments". The survey collected data from 286 randomly selected farm households in five selected villages located in the two major rice growing regions of the Philippines during the period 1985-86 and 1989. The transactions analyzed included all pawning transactions for the $1985-89$ period reported by the households based on recall in $1989^{3}$.

Table 1 presents the socioeconomic characteristics of the sample households. Region 1 is more progressive in rice cultivation and more urbanized than Region 2 which is characterized by more rugged terrain and is located farther from the metropolitan center. The villages, V1 and V2 located in Region 1 and V3, V4 and V5 in Region 2, represent different production environments. While V1 and V3 are fully irrigated by gravity irrigation systems and grow two rice crops a year, V2 and V4 are characterized by favorable rainfed conditions with a few farms practicing double cropping. V5, a drought prone rainfed village, has the most unfavorable environment for rice growing. Modern rice varieties (MV) are fully adopted in V1, V2, and V3, whereas traditional varieties are still planted in the hilly part of V4 and the mountainous part of V5 during the wet season. Reflecting the differences in production environments and adoption of modern varieties, the average rice yield per hectare is significantly higher in the irrigated than in the rainfed villages, particularly in V5.

While land reform was well implemented in Region 1, it was not in Region 2. Under the 1972 land reform of rice and corn lands, share tenants were supposed to be converted 
either to leaseholders by Operation Leasehold when the landlord owned less than 7 hectares of land, or to Certificate of Land Transfer (CLT) holders under Operation Land Transfer when the landlord owned more than 7 hectares of land (Hayami, Quisumbing and Adriano). Before the implementation of land reform, Region 1 villages consisted of large rice haciendas covering more than 100 hectares and the majority of farmers were share tenants, so they were subject to Operation Land Transfer. Region 2 villages were characterized by small landlord operators also employing share tenants. But due to weak implementation of Operation Leasehold, the tenants received permanent leasehold rights and the landowners retained ownership. Otsuka demonstrated that increased residual gains due to modern technology raised the economic interests of the share tenants in demanding a more comprehensive implementation of land reform in Region 1 than in Region 2.

While the leasehold titles granted in Operation Leasehold areas in Region 2 can be "legally" transferred and therefore can be sold, land pawning is the only feasible way to transfer cultivation rights in the Operation Land Transfer areas of Region $1^{4}$. Not surprisingly, therefore, pawning contracts are more common in Region 1 than 2 (Table 2). Furthermore, the majority of pawned land in Region 1 is under CLT or leasehold tenure status, whereas in Region 2 pawning does not seem to be limited to land reform beneficiaries 5 .

An examination of mean loan sizes per hectare, controlling for tenurial status, revealed no significant patterns, except in $\mathrm{V} 1$ where the returns to rice farming are higher due to uniform land quality, and higher yields and cropping intensity. The differential access to informal credit appears to be based more on the supply of cultivation rights and 
quality of land than on tenurial status and related lending risk. This finding suggests a low risk of eviction if these illegal transactions are reported in an Operation Land Transfer area. There appear to be limited incentives for reporting these illegal transactions. If land received in an Operation Land Transfer area is pawned and the pawning is reported to the Department of Agrarian Reform, the land will revert to the farmers' organization ( Samahang Nayon) which allots it to another eligible former tenant on that parcel. But the majority of the pawning transactions were implemented with a written contract between friends and relatives so that long term relationships and known reputations established an information base and lowered the reporting risk.

The average loan size obtained with land pawning is significantly larger than other short term informal loans reported in Region 1 without land pawning (8640 Pesos in V1 and 2323 Pesos in V2) ${ }^{6}$. Furthermore, the imputed mean annual interest rate of pawning contracts usually ranged from 17 to 37 percent, while short-term informal loans typically carry a higher explicit interest rate of 50 to 60 percent per annum ${ }^{7}$.

\section{Conceptual Model}

Recent evidence suggests that short-term informal credit contracts (typically covering one crop season) with an explicit interest rate and without land collateral are generally available for financing production or consumption expenses (Esguerra and Meyer; Floro). But to obtain larger and longer-term loans, collateral is typically required in both the formal and informal credit markets. Table 2 indicates that the majority of the pawning contracts were undertaken to finance productive purposes -- education, overseas travel, start a new 
nonfarm business -- where the expected rate of return to the investment is considered higher than farming ${ }^{8}$. Hence, we can hypothesize that a liquidity constrained profit maximizing pawner will choose to pawn out land based on (i) expected rate of return to rice farming relative to alternative investments, and (ii) the implicit interest rate of the pawning contract relative to other sources of finance.

The returns to rice farming per hectare will be lower on lower quality land, i.e., unirrigated land where only one crop of rice can be grown, poor quality soils, and mountainous terrain ${ }^{9}$. Farm households with smaller farm size, fewer inherited assets and less education would be expected to view investments in rice farming, which is relatively land and capital intensive, as less remunerative over the long term than investments in non-farm employment, which is dependent mainly on the quantity and quality of family labor supply. Indeed, investments in non-farm employment may be more profitable than rice farming overall, but wealthier households either self finance or have access to formal financial markets to finance their investments while poorer farmers have to rely on land pawning. Thus, households with poorer quality land, smaller farm size, less education and fewer assets will tend to pawn out land to invest directly in non-farm employment in the overseas or local market or indirectly by improving human capital through education. It is also expected that households with other sources of income (e.g. non-farm) will be less likely to pawn out land. Furthermore, pawning may be essential for a farm household rationed out of other forms of formal and informal loans, or already too far in debt to obtain new loans without pawning. 
While pawners view rice farming as less profitable than other investments, pawnees who grant loans in exchange for temporary cultivation rights consider farming to be more profitable and hence forgo the return they would have earned by investing their funds elsewhere. This implies that profit maximizing liquidity and asset rich households accept pawned land when they have a comparative advantage in farming relative to other investment opportunities or when they lack good alternative investment opportunities. Thus, we would expect pawnees to have better quality land, larger farms, greater assets, and more education.

The prevalence of multiple tenurial status and limited transferability of land rights adds another dimension to pawning contracts in rice growing areas. Since owner cultivators have transferable land rights and therefore have access to collateralized formal loans, we expect that they will engage in fewer pawning contracts than land reform beneficiaries. Since pawning contracts are illegal, pawnees risk eviction if discovered by reform officials and this increases transaction costs. These costs can be internalized (ceteris paribus), however, by varying loan size per hectare according to the degree of risk involved. Furthermore, the eviction risk can be reduced by making loans only to borrowers with good reputations who are likely to repay loans. This implies that loan size per hectare should be positively associated with the tenurial status of the land pawned and the reputation of the participants, given land quality. 


\section{Econometric Analysis}

Regression models were used to examine the factors affecting the behavior of pawners and pawnees. First, a logit model was estimated to determine the probability of a household pawning out (in) land where the dependent variable takes a value of 1 if the household is a pawner (pawnee) during the reference period and 0 otherwise. Second, a tobit model was estimated to explain the observed loan size per hectare where the dependent variable is the loan amount for pawners (pawnees) and zero otherwise.

A common set of independent variables was specified in all equations referring to the year 1985 to avoid possible endogeneity problems. The independent variables include land quality as measured by annual net returns to land per hectare in rice farming (LQUALITY), and rice cropping intensity, an alternative measure of land productivity (RICEINT). Initial household asset endowments are represented by farm size in hectares (FSIZE), human capital denoted by years of schooling of the household head (EDUHH), market value of inherited nonland assets in Pesos (ASSETS), non farm income in Pesos (NONFARM), and ratio of number of dependents to total family members (DEPRATIO). The reputation of the household head was proxied by a stability index calculated as the ratio of years in the village to the age of the household head (REPUTATION). To examine the effect of tenurial status, the proportion of beneficiary land to total land operated by the household (CLTLH) and the proportion of non-beneficiary land to total land operated (OC) are included in the models. The region specific implementation of land reform is captured by the interaction variables (CLTLHxREGION, OCxREGION) and by a REGION dummy variable in which one represents Region 1. 
The model estimates are presented in Table 3. Pawners and pawnees tend to have opposite characteristics as evidenced by the opposite signs of several independent variables. The logit estimates in column two for the pawning out regression confirm our hypothesis that farm households deriving lower returns to farming tend to pawn out land for investments in non farm employment. The coefficient LQUALITY is negative and significant while that of farm size (FSIZE), though not statistically significant, has the expected negative sign. The ownership of nonland (ASSETS) and human assets (EDUHH) is negatively associated with the probability of being a pawner. The results also show that the probability of being a pawner increases significantly for beneficiary households in Region 1 where land reform was more comprehensively implemented than in Region 2 . The loan size per hectare is similarly affected by the same variables, as indicated by the tobit estimates. It is interesting to note, however, that once the pawning contract is chosen, rice cropping intensity (RICEINT, rather than LQUALITY) and reputation (REPUTE) become significant explanatory variables of loan size per hectare.

The pawnee functions show the expected results that asset rich farm households tend to be pawnees and negotiate larger loan sizes as evidenced by the positive and significant coefficients for farm size (FSIZE), inherited assets (ASSETS), and education of household head (EDUHH). While the coefficients of land quality (LQUALITY), also an indicator of wealth, are positive but not significant in both logit and tobit estimates, the rice cropping intensity (RICEINT) positively and significantly explains the loan size negotiated by the pawnees. The positive coefficient of farm size may not only indicate a wealth effect but also efficiency gains derived from specialization in rice farming. The fact that nonfarm income 
(NONFARM) has a significantly negative coefficient in both the logit and tobit regressions indicates that farm households who pawn in land tend to be specialized in farming. With larger farms and better land quality, pawnees tend to allocate relatively more time to farming than to non-farm enterprises. Negative but insignificant tenurial status variables (CLTLH; OC) explain pawnee behavior as one driven by the demand for cultivable land and a supply of liquid funds to generate a higher rate of return in farming.

\section{Conclusions and Policy Implications}

Land pawning contracts have increasingly been observed in Philippine rice growing villages. Our analysis showed that farm households generally pawn out land to finance investments for non-farm employment either directly through financing overseas employment or non-farm business or indirectly by investing in education to increase returns to non-farm employment. Farm households who pawn out land are those with poorer quality land, smaller farm sizes, fewer inherited assets, and lower educational attainments. Pawnees, on the other hand, are wealthier households with larger farm sizes, greater inherited assets, and higher levels of education who derive a higher return from land investments possibly due to economies of scale and lower cost of capital.

Since most pawners are land reform beneficiaries, fears have been expressed that pawning transactions will lead to an unequal distribution of land ownership, negating the spirit of the land reform. The fact that pawning contracts exist, however, indicates that the accumulation of land/cultivation rights by a few households cannot be prevented through prohibition of land transfers, but rather by raising the profitability of agricultural invest- 
ments, particularly for small scale farming. Furthermore, beneficiaries were granted productive assets through land reform. Now they need to be given the flexibility to use these assets to pursue household goals and earn the highest possible rate of return on them. For some, this will imply a dedication to rice farming. For others, it will imply transforming their cultivation rights into other assets for which they expect a higher return. An appropriate policy would be to either deregulate the restriction on the transfer of beneficiary land rights so that this land can be used as collateral for institutional loans, or to assist the formal financial institutions to effectively resolve the problems which present them from taking farmer cultivation rights as loan collateral. 


\section{Notes}

1. In 'sangland bili' arrangements, the pawner usually remained in actual possession of the land, but in the role of a share tenant to the creditor until the loans are repaid. Nonrepayment of loans within the contracted period resulted in sale of land which then acquired a 'fee simple' status (for further details refer McLennen). However, in recent pawning contracts, the cultivation rights are temporarily transferred to the lender in exchange for a loan and redeemed upon loan repayment.

2. The land reform restricted transfer of land rights by the beneficiaries to only their legal heirs. This suppressed the supply in the land market. On the one hand, higher residual gains accruing to farm operators due to new rice technology and fixed land rentals increased the prospects of higher farm income and hence the demand for cultivable land. The increased demand for investment funds could not be met by formal financial institutions because the restriction on transfer of beneficiary land titles limited the use of land as loan collateral. The pawning of land cultivation rights emerged as a response to these institutional changes.

3. Since a pawning transaction is a major decision for the household and involves a large volume of money, the quality of retrospective data is high.

4. While Certificates of Land Transfer are not transferable outside the immediate family, the leasehold title can be legally transferred upon the consent of the landlord, provided payment for the tenancy title is not involved.

5. A few cases were found where the creditor insisted on pawning rather than outright sale of ownership rights from owner cultivators to avoid problems with land retention limits prescribed by the Department of Agrarian Reform. Also a strong cultural orientation towards land ownership and cumbersome procedures and high transaction costs in the formal institutions may have induced some owner cultivators to prefer pawning.

6. Data on all credit market transactions of the sample households in Region 1 were collected for three consecutive seasons beginning June 1988. The loans reported were deflated by the 1985 consumer price index.

7. The implicit interest rate was computed as a percentage of mean net residual per hectare per annum earned from rice farming to mean loan size per hectare per annum. The negative implicit interest rate in RF3 was due to unusually low yields in 1985 due to crop damage.

8. Although a rigorous analysis could not be carried out to compare the rate of return on alternative investments with that in farming, a low rate of foreclosed contracts -- 6 percent of the contracts during the reference period in Region 1 and 14 percent in Region 2 -support the argument. 
9. The introduction of modern rice varieties which are more suited to irrigated and favorable rainfed conditions has widened the profitability of rice farming between favorable and unfavorable production environments (David and Otsuka). 
Table 1 : Socioeconomic Characteristics of the Sample Households, 1985

\begin{tabular}{|c|c|c|c|c|c|}
\hline \multirow[t]{2}{*}{ Item } & \multicolumn{2}{|c|}{ Region 1} & \multicolumn{3}{|c|}{ Region 2} \\
\hline & $\mathrm{V} 1$ & $\mathrm{~V} 2$ & V3 & V4 & V5 \\
\hline No. of Sample HH & 85 & 52 & 37 & 65 & 47 \\
\hline Percent Area Irrigated & 100 & 16 & 100 & 0 & 0 \\
\hline Percent MV Adoption & 100 & 100 & 100 & 79 & 59 \\
\hline Rice Cropping Intensity & 200 & 114 & 243 & 131 & 125 \\
\hline Farm Size (ha.) & 2.1 & 1.7 & 1.1 & 1.4 & 0.9 \\
\hline Yield (ton/ha.) & 4.7 & 3.4 & 3.6 & 2.9 & 1.9 \\
\hline \multicolumn{6}{|c|}{$\frac{\text { Tenurial status of sample farms (Percent of area }}{\text { operated) }}$} \\
\hline Beneficiaries $^{\text {a }}$ & 85 & 81 & 37 & 27 & 17 \\
\hline Non-Beneficiaries ${ }^{b}$ & 13 & 18 & 28 & 50 & 39 \\
\hline Share Tenants & 2 & 1 & 35 & 23 & 44 \\
\hline
\end{tabular}

a Refers to Certificate of Land Transfer (CLT) and Lease Hold (LH).

b Refers to Owner Cultivators (OC). 
Table 2 : Profile of the Pawning Contracts, $1985-89^{\text {a }}$.

\begin{tabular}{|c|c|c|c|c|c|}
\hline \multirow[t]{2}{*}{ Item } & \multicolumn{2}{|c|}{ Region 1} & \multicolumn{3}{|c|}{ Region 2} \\
\hline & V1 & $\mathrm{V} 2$ & V3 & V4 & V5 \\
\hline No. of Pawning $\mathrm{HH}$ & 56 & 18 & 5 & 9 & 12 \\
\hline No. Pawning Contracts & 84 & 30 & 5 & 15 & 18 \\
\hline $\begin{array}{c}\text { Percent of Pawned Land Under } \\
\text { Beneficiary Status }{ }^{b}\end{array}$ & 97 & 74 & 60 & 0 & 0 \\
\hline $\begin{array}{r}\text { Percent of Pawned Land Under } \\
\text { Non-Beneficiary Status }\end{array}$ & 3 & 26 & 40 & 100 & 100 \\
\hline \multicolumn{6}{|l|}{ Loan Size in ${ }^{\prime} 000 \mathrm{P} /$ ha. $/$ Contract $^{\mathrm{d}}$} \\
\hline All Tenure Classes & 18.6 & 4.8 & 12.6 & 9.9 & 6.8 \\
\hline Beneficiaries & 19.1 & 4.9 & 17.6 & 0 & 0 \\
\hline Non-Beneficiaries & 36.1 & 4.6 & 6.9 & 9.9 & 6.8 \\
\hline $\begin{array}{l}\text { Implicit Interest Rate } \\
\quad(\% \text { Per Annum })\end{array}$ & 21.3 & 35.4 & 16.7 & 37.4 & -26.5 \\
\hline \multicolumn{6}{|c|}{ Purpose for Pawning Out ('000 P/ha./Contract with percent given in parentheses) } \\
\hline Productive Purposes & $\begin{array}{l}19.5 \\
(54)\end{array}$ & $\begin{array}{l}5.1 \\
(70)\end{array}$ & $\begin{array}{l}12.6 \\
(100)\end{array}$ & $\begin{array}{c}17.4 \\
(67)\end{array}$ & $\begin{array}{l}4.7 \\
(42)\end{array}$ \\
\hline Consumptive Purposes & $\begin{array}{l}17.8 \\
(46)\end{array}$ & $\begin{array}{l}4.6 \\
(30)\end{array}$ & $\begin{array}{l}0 \\
(-)\end{array}$ & $\begin{array}{c}6.2 \\
(33)\end{array}$ & $\begin{array}{c}3.9 \\
(58)\end{array}$ \\
\hline
\end{tabular}

a Pawned-out and Pawned-in contracts are aggregated from 1985 to 1989.

b Refers to Certificate of Land Transfer (CLT) and Lease Hold (LH).

c Refers to Owner Cultivators (OC).

d Loan size is deflated by consumer price index (base $=1985)$.

e Estimated as the percentage ratio of net residual from rice per year per hectare to loan size per hectare. The net residual is the total value of output minus cost of current inputs, fixed capital, labor and land rental payments. 
16

Table 3: Regression Results of Determinants of Pawn Out/In Decisions (Logit Analysis) and Corresponding Loan Size Per Hectare (Tobit Analysis)

\begin{tabular}{lccccc}
\hline & \multicolumn{2}{c}{ Pawner } & & \multicolumn{2}{c}{ Pawnee } \\
\cline { 2 - 3 } \cline { 5 - 6 } & Logit & Tobit & & Logit & Tobit \\
\hline INTERCEPT & $-1.86^{* *}$ & $-1.16^{* *}$ & & $-2.69^{* *}$ & $-1.39^{*}$ \\
LQUALITY & $-0.17^{* *}$ & $-0.74^{*}$ & & 0.71 & 0.24 \\
RICEINT & $0.14^{*}$ & $0.84^{*}$ & & 0.12 & $0.36^{*}$ \\
FSIZE & -0.18 & $-0.25^{*}$ & & $0.14^{*}$ & $0.32^{*}$ \\
EDUHH & $-0.12^{*}$ & $-0.78^{* *}$ & & $0.16^{* *}$ & $0.77^{* *}$ \\
ASSETS & $-0.11^{* *}$ & $-0.51^{* *}$ & & $0.49^{* *}$ & $0.27^{* *}$ \\
NONFARM & $-0.25^{*}$ & $0.37^{*}$ & & $-0.13^{*}$ & $-0.05^{*}$ \\
DEPRATIO & -0.17 & 0.54 & & $-0.53^{*}$ & -0.14 \\
REPUTATION & 0.53 & $0.29^{*}$ & & $0.75^{*}$ & $0.26^{*}$ \\
CLTLH & -0.69 & $-0.33^{*}$ & & $-0.13^{*}$ & -0.40 \\
OC & 0.97 & 0.54 & & -0.45 & -0.39 \\
CLTLHxREGION & $2.16^{*}$ & $1.21^{* *}$ & 0.92 & 0.37 \\
OCxREGION & 0.27 & $0.31^{*}$ & 0.22 & 0.27 \\
REGION & 0.67 & 0.52 & 0.52 & $0.37^{*}$ \\
Log-likelihood & -262.51 & -578.90 & -230.65 & -525.65 \\
Chi-square & 105.24 & & $59.17^{*}$ & \\
\hline
\end{tabular}

${ }^{* *},{ }^{*}$ represent significance at 1 percent and 5 percent, respectively. 


\section{.}




\section{References}

Adams, Dale W and Virginia Nazarea Sandoval, "Informal Rural Finance in the Philippines", Department of Agricultural Economics and Rural Sociology, The Ohio State University, ESO Paper No. 1570, 1989.

Bautista, Ernesto and M. Magno, "Overall Changes in the Structure and Operation of Rural Informal Credit Markets in the Philippines", Paper presented at the Seminar Workshop on Rural Savings and Informal Credit in the Context of Financial Liberalization, June 6-7, Central Bank, Manila, Philippines, 1990.

Binswanger, Hans and M. Rosenzweig, "Behavioral and Material Determinants of Production Relations in Agriculture", Journal of Development Studies, Vol. 22, No. 3, April, 1986, pp. 503-39.

David, Cristina C. and Keijiro Otsuka, "Differential Impact of Modern Rice Technology Across Production Environments in Asia", Paper presented at the Final Conference on the Differential Impact of the Modern Rice Technology Across Production Environments, March 25-28, International Rice Research Institute, Philippines, 1990.

Esguerra, Emmanuel F. and Richard L. Meyer, "Collateral Substitutes in Rural Informal Financial Markets : Evidence from an Agricultural Rice Economy", Paper Presented at the Seminar on Informal Financial Markets in Development, Washington, D.C., October 18-20, 1989.

Floro, Sagrario L., "Credit Relations and Market Interlinkages in Philippine Agriculture", Unpublished Ph.D. Dissertation, Stanford University, 1987.

Hayami, Yujiro, Agnes Quisumbing and Lourdes Adriano, Toward an Alternative Land Reform Paradigm : A Philippine Perspective, Quezon City: Ateneo de Manila University Press, 1990.

McLennan, Marshal S., "Land and Tenancy in the Central Luzon Plain", Philippine Studies, October 1969.

Nagarajan, Geetha, Agnes Quisumbing and Keijiro Otsuka, "Land Pawning in the Philippines : An Exploration into the Consequences of Land Reform Regulation", Working Paper, International Rice Research Institute, Philippines, 1990.

Onchon, Tongroj, "Informal Rural Finance in Thailand : An Overview", Paper Presented at the Seminar on Informal Financial Markets in Development, Washington D.C., October 18-20, 1989. 
Otsuka, Keijiro, "Determinants and Consequences of Land Reform Implementation in the Philippines", International Rice Research Institute, Philippines, Mimeo, 1989.

Wijaya, Hesti and Sturgess, N. H., "Land Leasing in East Java", Bulletin of Indonesian Economic Studies, Vol. 15, No. 2, 1981, pp. 75-93. 


\section{. . .}


, . 